\title{
LAS IMÁGENES DE LO SAGRADO O CÓMO SER CATÓLICO ENTRE CAMBIOS Y CONTINUIDADES (C. 1875-1931)
}

\author{
THE IMAGES OF THE SACRED \\ OR HOW TO BE A CATHOLIC BETWEEN \\ CHANGES AND CONTINUITIES (C. 1875-1931)
}

\author{
Joseba Louzao Villar \\ Centro Universitario Cardenal Cisneros \\ Universidad de Alcalá de Henares
}

Entregado el 15-1-2015 y aceptado el 4-6-2015.

Resumen: ¿Qué significó ser católico en la España de entre siglos? Cualquier intento de respuesta no puede ser en estos momentos más que un mero acercamiento parcial. Este trabajo pretende describir el catolicismo desde la perspectiva particular de la historia de la espiritualidad, remarcando la importancia que tuvieron las imágenes religiosas entre la devociones de los católicos españoles de entre siglos. Las imágenes religiosas no deben ser una mera anécdota dentro de la historia sociocultural religiosa, ya que fueron un recurso más en los planteamientos de «modernidad defensiva» de la Iglesia católica. Y es que la imaginería católica tuvo repercusiones en la vida cotidiana de los católicos y en su interpretación de la realidad. Detrás de las imágenes religiosas se encontraba una forma de entender el mundo y de relacionarse con él.

Palabras clave: imágenes sagradas, catolicismo, España, s. XIX-XX

\footnotetext{
Abstract: What did it mean to be a Catholic in Spain between the XIX and the $\mathrm{Xx}$ centuries? This article aims to describe spanish Catholicism from the particular perspective of the history of his spirituality, stressing the importance they had the religious images in the catholic devotions between the spanish Catholics from this two centuries in the Restoration period. This religious im-
} 
ages shouldn't be a simple anecdote within the religious cultural history, because they were a resource in the particular defensive modernity that defended the Catholic Church then. This religious images shouldn't be a simple anecdote within the religious cultural history, because they were a resource in the particular defensive modernity that defended the Catholic Church in those moments. In that sense, the Catholic imagery had an impact on the daily lives of Catholics and their interpretation of the reality. In conclusion, the sacred images was a way of understanding the world.

Key words: Sacred images, Catholicims, Spain, XIX-XX centuries 
Durante la Restauración, la sociedad española mantuvo un marcado carácter católico, que comenzaba con la propia Constitución de 1876 que declaraba que España era un país confesional. El Estado afianzó sus relaciones con la Iglesia, no sin los correspondientes conflictos, ofreciendo una estabilidad institucional regida por el Concordato de $1851^{1}$. Por su parte, la Iglesia aprovechó su tradicional monopolio sobre los momentos más importantes de la vida. De esta forma, estaba presente en los hitos claves desde el nacimiento hasta la muerte. La preeminencia social de la Iglesia católica descansaba sobre la influencia de sus sacerdotes en las diversas situaciones de la vida comunitaria e individual ${ }^{2}$. Además se encontraba presente en el paisaje público a través de iglesias y conventos, en el nomenclátor de las calles, en la enseñanza escolar o en el espacio simbólico que ocupaba con las anuales celebraciones religiosas. Ejercía así una decisiva influencia en la construcción de los modelos sociales, morales, familiares y educativos. Por esta razón, especialmente en el norte peninsular y entre las clases medias, la coyuntura favorecía la transmisión de una moral, una fe y una serie de valores que conformaban la cultura dominante. Pero no indiscutiblemente: en paralelo crecía el número de personas que se alejaban de la Iglesia. En aquellos años, especialmente a partir de la crisis política, social y cultural desencadenada por el fracaso colonial de 1898, la tradición anticlerical se revitalizó con la movilización callejera y la constante reproducción de estereotipos anticlericales en el espacio urbano ${ }^{3}$.

Con todo, ¿qué significó ser católico entonces? Cualquier intento de respuesta no puede ser en estos momentos más que un mero acercamiento parcial. Sin embargo, una visión panorámica puede abrir un amplísimo abanico de posibilidades, tanto a nivel historiográfico como metodológico. El plural está elegido conscientemente, ya que no hubo una sola forma de ser católico. Por desgracia, estos aspectos siguen siendo una de las lagunas de la historiografía religiosa española, más si lo que se

${ }^{1}$ Cristóbal Robles, Insurrección o legalidad: los católicos y la Restauración, Consejo Superior de Investigaciones Científicas, Madrid, 1988 o Andrés Martínez Esteban, Aceptar el poder constituido. Los católicos y la Santa Sede en la Restauración (1890-1914), Publicaciones de la Facultad de Teología San Dámaso, Madrid, 2006.

2 Antón Pazos, «Parroquias y clero parroquial», en Benoît Pellistrandi (éd.), L 'histoire religieuse en France et en Spagne, Collection de la Casa de Velázquez, Madrid, 2004, pp. 201-224.

3 Julio de la Cueva y Feliciano Montero (eds.), La secularización conflictiva. España (1898-1931), Biblioteca Nueva, Madrid, 2007. 
pretende es su integración en una historia general ${ }^{4}$. En ocasiones parece como si la espiritualidad estuviera bajo sospecha y, sobre todo, alejada de los posibles temas a incluir en el campo académico ${ }^{5}$. Además, en la raíz de muchas de las interpretaciones, se trata de explicar la evolución del catolicismo español exclusivamente desde una perspectiva política sin tener en cuenta las repercusiones de lo espiritual en todos los ámbitos vitales ${ }^{6}$. Durante estas décadas, los católicos españoles, al menos los que participaban militantemente, habían interiorizado una vivencia religiosa y espiritual inseparable de su participación pública ${ }^{7}$. Por su parte, la conocida como «masa neutra» del catolicismo se encontraba dentro de un marco simbólico del que tampoco solían escapar los individuos más pretendidamente partidarios del laicismo. De cualquier forma, y atendiendo a uno u otro caso, es necesario acercarse a este tipo de análisis para aclarar algunas de las líneas generales interpretativas, que muchas veces están asentadas en bases endebles y apriorísticas. No olvidemos que el caso español encaja a la perfección con la «segunda edad confesional»a la que se refería Olaf Blaschke para describir la etapa que se encuentra delimitada entre 1830 y $1960^{8}$.

Este trabajo pretende describir el catolicismo desde una perspectiva centrada en la historia de la espiritualidad, remarcando la importancia que tuvieron las imágenes religiosas entre los católicos españoles de entresiglos. Lo devocional sigue estando en el debe historiográfico español, probablemente porque se necesita trabajar con una mirada diferente, pero cada vez existe un mayor número de investigaciones que perfilan el pai-

4 Óscar Álvarez Gila, «La Historia de la Iglesia: posibilidades y problemas», Prohistoria, 6 (2002), pp. 169-171.

5 Ya lo señalaron Antón Pazos (ed.), La historia religiosa en Europa. Siglos XIX-XX, Ediciones de Historia, Madrid, 1995 y José Manuel Cuenca Toribio «La historiografía eclesiástica española contemporánea. Balance provisional a fines de siglo (1976-1999)», Hispania Sacra, 103 (1999), p. 355.

${ }^{6}$ Baldomero Jiménez Duque, La espiritualidad en el siglo XIX español, Universidad Pontificia de Salamanca/ Fundación Universitaria Española, Madrid, 1974 e ÍD., «Espiritualidad y apostolado», en Ricardo García-Villoslada (dir.), Historia de la Iglesia en España. Vol. 5: La Iglesia en la España Contemporánea, Biblioteca de Autores Cristianos, Madrid, 1979, pp. 395-474.

7 Joseba Louzao, Soldados de la fe o amantes del progreso. Catolicismo y modernidad (1890-1923), Genueve Ediciones, Logroño, 2011.

8 Olaf Blaschke, Offenders or Victims? German Jews and the Causes of Modern Catholic Antisemitism, The Hebrew University of Jerusalem-University of Nebraska Press, Jerusalén-Lincoln, 2009. 
saje histórico ${ }^{9}$. Por ello, nos interesa acercarnos a las imágenes religiosas para que nos ofrezcan la apertura de una ventana más, que no la única, hacia la comprensión el hecho religioso como tal y, hasta el momento, se trata de una asignatura pendiente en la parcela del contemporaneísmo hispano. La mentalidad y el imaginario católico se asentaban en ellas. Como señalaron Jaume Aurell y Pablo Pérez López, el vacío historiográfico en relación a la historia espiritual es «un panorama parangonable al que tendríamos si alguien que trabaja sobre historia de España no supiera bien qué es un sindicato o cuáles son las funciones propias de un ministerio, y escribiera de esos asuntos por aproximación: en lo posible evitaría esas cuestiones, y cuando las tratara, difícilmente no caería en imprecisiones y errores por más que intentara evitarlos» ${ }^{10}$.

Sorprendentemente existe un campo amplio con documentación y fuentes accesibles esperando. Por otro lado, los avances de las últimas décadas en relación a la religión nos están permitiendo escapar del relato establecido por el paradigma secularizador ${ }^{11}$. Como consecuencia, podemos plantear cuestiones y relaciones novedosas que hasta el momento estaban ocultas o desdeñadas. Modernidad y catolicismo son dos de los ejes históricos más interesantes que tenemos para ofrecer nuevas explicaciones sobre uno de los grandes claveages políticos, sociales y culturales de la historia española contemporánea. Las imágenes religiosas no deben ser una mera anécdota dentro de la historia sociocultural religiosa, ya que fueron un recurso más en los planteamientos de «modernidad defensiva» de la Iglesia católica, un concepto que pretende recoger la tensión vivida en ámbitos culturales entre lo moderno y tradicional. Y es que, en paralelo a las diversas condenas al mundo moderno, la Iglesia actuó como un

9 Federico M. Requena, La revista La Vida Sobrenatural (1921-1928). Una aportación a la historia de la vida espiritual en la España contemporánea, Universidad de Navarra, Pamplona, 1999, ÍD., «Vida religiosa y espiritual en la España de principios de siglo XX», Anuario de Historia de la Iglesia, 11 (2002), pp. 39-68, o ÍD., Católicos, devociones y sociedad durante la Dictadura de Primo de Rivera y la Segunda República. La Obra del Amor Misericordioso en España (1922-1936), Biblioteca Nueva, Madrid, 2008.

10 Jaume Aurell y Pablo Pérez López, «La historia religiosa y su dimensión sociológica», en Jaume Aurell y Pablo Pérez López, (eds.), Católicos entre dos guerras. La historia religiosa de España en los años 20 y 30, Biblioteca Nueva, Madrid, 2006, p. 19.

11 Joseba Louzao, «La recomposición religiosa en la modernidad: un marco conceptual para comprender el enfrentamiento entre laicidad y confesionalidad en la España contemporánea», Hispania Sacra, 121 (2008), pp. 331- 354 y en este mismo número el trabajo de Julio de la Cueva. 
activo agente de modernización utilizando los medios que la modernidad había puesto a su alcance para recomponer sus tradiciones y recrear su memoria $^{12}$.

En definitiva, este artículo pretende ofrecer una primera aproximación a la historia espiritual del catolicismo español de entresiglos desde un planteamiento asentado en las claves heurísticas del paradigma indiciario establecido por Carlo Ginzburg ${ }^{13}$. Debemos aprovechar estas huellas e indicios que nos permiten descifrar una realidad que, a veces, se mantiene velada y opaca. Por lo tanto, nuestro interés no se concentra tanto en las imágenes como artefacto cultural, aunque somos conscientes de la importancia de esta tipología de análisis, sino como creadoras de un imaginario que tuvo repercusiones cotidianas entre los católicos, convirtiéndose así en indicios que nos ayudan a leer y descifrar la manera de ser católico de aquellas personas ${ }^{14}$.

\section{La espiritualidad y los católicos españoles}

Suele ser habitual distinguir entre una piedad culta y otra popular ${ }^{15}$. Como sabemos, lo popular está cargado de ambigüedades y prejuicios. Precisamente por su polisemia creemos que se trata de un concepto insatisfactorio, aunque no tenemos espacio para alegar todas las razones, ni mucho menos profundizar en ellas. En cualquier caso, cuando se habla

${ }^{12}$ La modernidad defensiva en Francisco Javier Caspistegui, «Modernidad defensiva: propuesta de concepto», texto inédito presentado al Seminari d'Historia Cultural Universitat de València, Valencia 2010. Además, Michel Lagrée, Religion et cultures en Bretagne (1850-1950), Fayard, Paris, 1992, Étienne Fouilloux, «Iglesia Católica y mundo moderno (siglo XIX y XX)», en Paul Aubert (ed.), Religión y sociedad en España (siglos XIX y XX), Casa de Velázquez, Madrid, 2002, pp. 81-84 o Danièle Hervieu-Léger, La religión, hilo de memoria, Herder, Barcelona, 2005.

13 Carlo Ginzburg, Mitos, Emblemas, Indicios. Morfología e Historia, Gedisa, Barcelona, 1989 e ÍD, Tentativas, Universidad Michoacana de San Nicolás de Hidalgo, Michoacán, 2003.

${ }^{14}$ En este sentido puede ser interesante el análisis de Isabelle Saint-Martin, Art chrétien, art sacré: regards du catholicisme sur l'art, France, XIXe-XXe siècle, Presses Universitaires de Rennes, Rennes, 2014.

15 Frances Lannon Privilegio, persecución y profecía. La Iglesia en España, 18751975, Alianza, Madrid, 1990, William J. Callahan, La Iglesia Católica en España (18752002), Crítica, Barcelona, 2002, y José Andrés- Gallego y Antón M. Pazos, La Iglesia en la España contemporánea I. 1800-1936, Encuentro, Madrid, 1999. 
de religiosidad popular se termina por hacer referencia a una formulación vaga que incluye desde prácticas no aprobadas por la jerarquía eclesiástica hasta definiciones que se acercarían a ciertas manifestaciones mágicas o supersticiosas, pasando por la identificación con la religión cotidiana de las personas corrientes. Sin embargo, cualquier definición que, desde el papel, podría ser aceptable, no soporta una aplicación a la realidad. Lo que se agrava por la falta de estudios en la historiografía contemporánea de gran calado, más allá de la propia literatura pastoral de la Iglesia ${ }^{16}$. Teniendo en cuenta todo lo anterior, la riqueza de estas variables ambivalentes a lo largo del tiempo hacen casi imposible una conclusión firme sobre la problemática de la religiosidad popular. Lo veremos a lo largo de este texto: habrá comportamientos que se definirían plenamente como populares de los que participaban los agentes eclesiásticos, incluso de la denominada jerarquía. Y también nos encontraremos con elementos ortodoxos, incluso cultos, que se convirtieron en manifestaciones completamente populares. Aún con todo, la negación de la validez de las definiciones disponibles no elimina el problema. La hibridación es tal que quizá haya que hacer caso al antropólogo Manuel Delgado: «el nombre que recibe el conglomerado de esas prácticas y creencias no es otro que el de, sencillamente, religión ${ }^{17}$.

Ante la riqueza y diversidad de la vivencia espiritual y piadosa de la época, es más interesante tomar conciencia de la noción de «circulación de las devociones», con la que ya han comenzado a trabajar una serie de especialistas en la historiografía francesa ${ }^{18}$. Para Bernard Dompnier, esta perspectiva expresa los cambios y la evolución que se producen en torno a las devociones, que tienen un carácter eminentemente movedizo a nivel cultural, social y geográfico, atendiendo a la emergencia de las mismas, sus prácticas y expresiones y su difusión a través de los diversos grupos

16 Jorge Uría, «La cultura popular y la historiografía española contemporánea: breve historia de un desencuentro», en Manuel Ortiz Heras, David Ruiz e Isidro Sánchez Sánchez (coords.), Movimientos sociales y Estado en la España contemporánea, Universidad de Castilla- La Mancha, Cuenca, 2001, pp. 361-362 y Demetrio Castro, «La religiosidad popular en España. De la crisis del Antiguo Régimen a la sociedad industrial. Algunas cuestiones para su estudio», en Jorge Uría (coord.), La cultura popular en la España Contemporánea. Doce estudios, Biblioteca Nueva, Madrid, 2003, pp. 29-43.

17 Manuel Delgado, «La religiosidad popular. En torno a un falso problema», Gazeta de Antropología, 10 (1993), s.p.

18 Véanse los trabajos recogidos en «La circulation des dévotions» de la revista Siècles, 12 (2000). 
creyentes ${ }^{19}$. Además, prestar atención a las devociones y sus diferentes formas puede suministrar conocimiento sobre algunas de las respuestas que la Iglesia utilizó en su recomposición ante los acontecimientos de los tiempos ${ }^{20}$. Entre los siglo XIX-XX se produce la revalorización de ciertas devociones e, incluso, la creación de otras nuevas provenientes de Fran$\mathrm{cia}^{21}$. Este tipo de devociones en origen eran vigiladas estrechamente por el Santo Oficio, ya que durante la década de los veinte y treinta se pusieron de moda devociones privadas ligadas a distintas visiones, que en ocasiones escaparon del marco litúrgico y devocional católico como, por ejemplo, las propias apariciones de Ezquioga en Guipúzcoa ${ }^{22}$.

También en este caso las diferencias entre la ciudad y el mundo rural fueron considerables. Los cambios se observaron mejor en la ciudad, pero esto no quiere decir que las transformaciones no se dejaran notar en el universo rural $^{23}$. Por tanto, se debe poner en cuestión interpretaciones estáticas de una realidad mucho más compleja de lo que a veces pretendemos. Lo nuevo y lo tradicional convivieron en el interior de las propias personas. En otras palabras, existieron diversas formas de ser católico y también, si atendemos a la constatada feminización religiosa de la época, de ser católica ${ }^{24}$. Sin embargo, este trabajo necesita de muchas más investigaciones, ya que en numerosos puntos nos movemos por intuiciones generales que quizá también se encuentren repletas de prejuicios.

19 Bernard Dompnier, «Introduction. Les dévotions aussi ont une histoire», Siècles, 12 (2000), pp. 6-7.

20 Bernard Berthod y Elisabeth Hardouin-Fugier, Dictionnaire des objets de dévotion dans l'Europe catholique, Amateur, Paris, 2006 y Ann Ball, Encyclopedia of Catholic Devotion and Practices, Our Sunday Visitor Publishing, Huntington, 2002.

${ }^{21}$ Sin dejar de lado devociones falsas que se calificaban de «tonterías» (R. V. Ugarte, «Lo que debemos hacer», El Mensajero del Corazón de Jesús y del Apostolado de la Oración, t. LIV, XII- 1912, p. 530).

22 William A. Christian, Las visiones de Ezkioga. La Segunda República y el Reino de Cristo, Ariel, Barcelona, 1997 y Joseba Louzao, «La Virgen y la salvación de España. Un ensayo de historia cultural durante la Segunda República», Ayer, 82, 2011, pp. 187-210

${ }_{23}$ Pedro Berriochoa, Como un jardín. El caserío guipuzcoano entre los siglos XIX y XX, Universidad del País Vasco, Bilbao, 2014.

${ }^{24}$ Inmaculada Blasco, «Género y religión: de la feminización de la religión a la movilización católica femenina. Una revisión crítica», Historia Social, 53 (2005) pp. 120-121, James McMillan, «Religion and Gender in Modern France: Some Reflections» en Frank Tallet y Nicholas Atkin (eds.), Religion, Society and Politics in France since 1789, The Hamblendon Press, London, 1991, pp. 55-66 o Claude Langlois, Le Catholicisme au féminin. Les congrégations françaises à supérieure générale au XIXe siècle, Les Éditions du Cerf, Paris, 1984. 
En el caso del catolicismo español, la espiritualidad residía en diversas devociones con implicaciones diarias, tanto personales como comunitarias (las más importantes devociones de la época, como en el resto de la Europa católica, fueron las del Sagrado Corazón, la Virgen María, la Eucaristía y la del Pontífice romano ${ }^{25}$. La Iglesia las gestionaba a partir de sus agentes eclesiásticos, y se encontraban en santuarios, parroquias o conventos. No se puede olvidar que este bagaje espiritual formaba parte de la configuración de la cultura política del movimiento católico español, basada en un activo nacionalcatolicismo antiliberal, de fuerte carácter martirial, que tuvo importantes efectos sobre la movilización y la acción colectiva, aunque también existieron militantes católicos en los partidos políticos liberales ${ }^{26}$. Además, las redes de sociabilidad devocional han sido desdeñadas por encontrarse en coordenadas muy alejadas a las actuales $\mathrm{y}$, sin embargo, nos ofrecen datos sobre la socialización personal indispensables para entender la realidad de la época. De hecho, fueron constantes las noticias de nuevas fundaciones de asociaciones u organizaciones relacionadas con este ámbito de la piedad católica. Aunque también se hace necesario señalar que los católicos desmovilizados, salvo en situaciones concretas, seguían siendo una mayoría considerable. Estas implicaciones ganan peso por el hecho de que, sobre todo a partir de la década de los diez, eran patentes los efectos de la pérdida de influencia social de los agentes eclesiásticos y de la práctica religiosa. La dictadura de Primo no pudo cambiar esta evolución, como demuestra la preocupación de numerosos religiosos españoles, en especial aquellos que tuvieron una visión privilegiada desde su labor social, sobre el abandono del catolicismo en algunas zonas del país ${ }^{27}$.

25 David Morgan, The Sacred Heart of Jesus: The Visual Evolution of a Devotion, Amsterdam University Press, Amsterdam, 2008; Bruno Béthouart y Alain Lottin (eds.), La dévotion mariale de l'an mil à nos jours, Artois Presses Université, Arras, 2005 o Miri Rubin, Mother of God. A History of the Virgin Mary, Allen Lane, London, 2009; y Bruno Horaist, La Dévotion au Pape et les catholiques français sous le pontificat de Pie IX (18461878), École Française de Rome, Roma, 1995.

${ }^{26}$ Joseba Louzao, «Nación y catolicismo en la España contemporánea. Revisitando una interrelación histórica», Ayer, 90 (2013), pp. 65-89 y Julio de la Cueva, «Cultura y movilización en el movimiento católico de la Restauración (1899- 1913)», en Manuel Suárez Cortina, Manuel (ed.), La cultura española en la Restauración, Sociedad Menéndez Pelayo, Santander, 1999, pp. 169-192 o ID., «Católicos en la calle: la movilización de los católicos españolas, 1899-1923», Historia y Política, 3 (2000), pp. 55-80.

${ }_{27}$ Feliciano Montero, «La apostasía de las masas y la recristianización de la sociedad: las estrategias pastorales de la Iglesia española en el siglo XX», El siglo XX: balance y perspectivas, Valencia, Universitat de València, 2000, págs. 391-398. 


\section{Las imágenes religiosas: algo más que catequesis}

Durante la Restauración los católicos se encontraban inmersos en un mundo de imágenes. De hecho, tanto si se era creyente o no, era difícil que pasara un día sin contemplar alguna figura religiosa. Es, por tanto, imposible comprender algunos de los usos populares de la religiosidad, o también del anticlericalismo, sin constatarlo. Como señalaba en los años republicanos el escritor argentino Roberto Arlt, que se encontraba de viaje por España, «aquí se nace, se vive, se juega, se sufre, se ama, se trabaja, entre imágenes» ${ }^{28}$. En este sentido, sobresalían por su profusión y variedad las imágenes en las que se representaban a la Virgen y Jesucristo, especialmente las relacionadas con la devoción corazonista. El polígrafo navarro Bernardo Estornés describió la casa familiar de su infancia de manera significativa: «los muebles eran una cómoda con varios cajones con objetos sobre ella, destacando un corazón de Jesús de regular tamaño. En las paredes, cuadros de santos y fotografías ${ }^{29}$.

El desarrollo devocional favoreció en la España de entresiglos una presencia prolífica de esta imaginería, que tenía su propia repercusión en el ámbito de la cultura política católica. En un segundo plano, pero de forma significativa, nos encontramos con las representaciones de santos locales y, más minoritariamente, de los ángeles, figuras de predilección infantil. Las imágenes se podían llevar encima, a través de una gran variedad de medallas y escapularios, o se encontraban en cada una de las habitaciones de los hogares. Pero no sólo se podían observar en el ámbito privado. Además de su tradicional presencia en las calles, a pesar de los intentos del Estado moderno por apropiarse del espacio público, los niños reparaban en ellas en los colegios y los padres lo podían hacer en las fábricas y sus diferentes lugares de trabajo ${ }^{30}$. Cada pueblo tenía su propia advocación mariana y sus santos patronos, que se convertían en una presencia cotidiana dentro de la localidad, conformando una memoria tradicional que iba mucho más allá de los días marcados en el calendario de festividades locales y que se rellenó de un importante contenido político en las coronaciones marianas que se hicieron a lo largo del

\footnotetext{
28 Roberto Arlt, Aguafuertes vascas, Simurg, Buenos Aires, 2005, p. 92.

29 Bernardo Estornés Lasa, Memorias. Recuerdos y andanzas de casi un siglo, Auñamendi, Donostia, 1996, p. 29.

${ }_{30}$ Carlos Reyero, La escultura conmemorativa en España. La edad de oro del monumento público, 1820-1914, Cátedra, Madrid, 1999, p. 399.
} 
país en el período de entresiglos en un contexto de intensa movilización anticlerical ${ }^{31}$. Cualquier población rural o ciudad española nos podría ofrecer un ejemplo paradigmático de esta realidad. De hecho, las calles de las ciudades estaban repletas de hornacinas que contenían representaciones de diferentes figuras religiosas. La identidad católica se comenzaba a construir desde estos parámetros, y tuvo sus implicaciones sociopolíticas.

Asimismo, estos espacios fueron dardo fácil de los arrebatos anticlericales en los motines y disputas de principios de siglo. Para los católicos, estos sacrilegios sólo podían paliarse con actos en desagravio. Fue una constante de la época, a cada acto anticlerical se respondía con una celebración de desagravio. Si siguiéramos la pista a los sermones pronunciados en estas ocasiones, obtendríamos una magnífica radiografía de la cultura política nacionalcatólica de la época. A finales de 1917, la imagen de la virgen de Begoña situada en una de las calles céntricas de Bilbao fue atacada por un grupo de anticlericales durante la última noche del año. El catolicismo local pronto se encargó de organizar una celebración en la que el sacerdote destacó que no hubo nadie para impedir el acto sacrílego porque «como creyentes y como vizcaínos», nadie podía concebir que hubiese alguien «capaz de hacer lo que se hizo» ${ }^{32}$. Era evidente que la identidad regional se construía a partir de la identidad religiosa y esta autoidentificación clasificaba claramente lo que estaba bien y lo que estaba mal. No era extraño dentro del discurso católico establecer una dicotomía entre el bien y el mal, la luz y la oscuridad ${ }^{33}$. En este sentido, es más sencillo que los creyentes religiosos participen activamente en la protesta y la aceptación de sus mecanismos si «caracterizan la vida como una lucha entre el bien y el mal» ${ }^{34}$. La teología política nacionalcatólica desarrollada

31 Se han contabilizado unas 73 coronaciones (cit. en Francisco J. Ramón Solans, La Virgen del Pilar dice.... Usos políticos y nacionales de un culto mariano en la España contemporánea, Prensas Universitarias de Zaragoza, Zaragoza, 2014, p. 217). Para el caso francés Paul d'Hollander y Claude Langlois (dirs.), Foules catholiques et régulation romaine. Les couronnements de vierges de pèlerinage à l'époque contemporaine (XIXe et XXe siècles), Presses universitaires de Limoges, Limoges, 2011.

32 El Pueblo Vasco, 14-I-1918.

33 Joseba Louzao, «Líbranos del mal...: Fragmentos para una historia del demonio en la España contemporánea (c. 1850-1939)», Historia, antropología y Fuentes Orales, 47-48 (2012), pp. 155-180.

${ }^{34}$ Rory McVeigh y David Sikkink, «God, Politics, and Protest: Religious Beliefs and the Legitimation of Contentious Tactics», Social Forces, $79 / 4$ (2001), p. 1427. 
en el catolicismo europeo de la época tenía sus repercusiones en la vida cotidiana más allá de recursos retóricos.

Y, por supuesto, también se encontraban las imágenes diseminadas por cada una de las parroquias y ermitas del país, ya fuera en retablos, cuadros o estatuas. Miguel de Unamuno describió una prototípica iglesia rural de finales de siglo XIX donde destacaba la activa presencia de las imágenes en el templo, por lo que merece la pena una cita extensa:

«Alguna vez se habrá fijado acaso en la cara de cera de aquella Dolorosa envuelta en su manto negro, del altar de la izquierda; tal vez en el San Antonio de aquel cuadro de sombras viejas y cielo de oro sucio del de la derecha, o en el San Juan en el desierto; acaso en las inevitables estampas de los lados del altar mayor; o en la Virgen española, morena, tosca, de vivos ojos y severo rostro, manto bordado y largo pelo tendido, con su niño vivaracho de traje bordado también, y coronados ambos, del flanco del evangelio; o en la Virgen francesa, de ceñido traje blanco con cintas azules, manos juntas y cara de lirio de puntura dirigida al cielo, del flanco de la epístola; habrá detenido su mirada en aquella Santa Isabel en el lecho, que tiene a su lado a san José y a la Virgen que mira cada cual a un lado, o la habrá reposado en aquel Cristo de encima, iluminado por la desfallecida luz que a través de las rojas cortinas se filtra» ${ }^{35}$.

A pesar de las transformaciones sociales y religiosas que se produjeron durante aquellas décadas, las imágenes seguían manteniendo un poder catequético de primer orden como pedagogas de la $\mathrm{fe}^{36}$. Como señalaba Isidro Gomá, por entonces canónigo de la metropolitana de Tarragona, «con la imaginería sagrada podría recomponerse nuestra historia religiosa [como] recordatorio perpetuo de la realidad viva que representan ${ }^{37}$. Los sacerdotes y religiosos no descuidaron este potencial, especialmente en el campo de las misiones populares ${ }^{38}$. Durante unos días, la finalidad pri-

35 Miguel de Unamuno, Obras Completas. VIII. Ensayos, Biblioteca Castro, Madrid, 2007, p. 344.

${ }^{36}$ Para profundizar en este valor catequético Isabelle Saint-Martin, Voir, savoir, croire. Catéchismes et pédagogie par l'image au XIXe siècle, Honoré Champion, Paris,2003.

37 Isidro Gomá, El valor educativo de la liturgia católica, Tipografía Católica Pontificia, Barcelona, 1918, p. 252.

38 Desgraciadamente aún no tenemos un acercamiento a este fenómeno de manera global desde una perspectiva de historia contemporánea. Por ello, pueden servir de ejemplo Francisco Luis Rico, Misiones Populares en España entre el Barroco y la Ilustración, Ins- 
mordial que buscaban era avivar la vida espiritual de los feligreses y reconvenir a los «indiferentes» y/o «pecadores» para que cumplieran con sus deberes como católicos. En la coyuntura religiosa de entresiglos, para la mayoría de las personas aún primaba lo emocional ${ }^{39}$. Por tanto, se trataba de conjugar a través de los sentimientos, lo individual y lo comunitario. Porque las misiones iban dirigidas a persuadir a todos los miembros de la comunidad de los peligros de apartarse de la vida cristiana y hablaban más al corazón que a la razón ${ }^{40}$. En esa semana - aunque la temporalización variaba - todo la localidad giraba en torno a la predicación y las actividades organizadas. En las ciudades, al ser más complicado por el ambiente, se solían elaborar misiones parciales para grupos de personas localizados en ciertas parroquias.

La salvación, el pecado, los novísimos (es decir, todo lo relacionado con la escatología) y la misericordia divina eran los contenidos del corpus establecido de las misiones. Los sermones más duros eran los del pecado y del juicio, donde se censuraba y señalaban los vicios y pecados más extendidos para buscar la culpabilidad del oyente. Con esta temática y el efectismo con los que se presentaban es lógico el despertar de distintas emociones, que iban desde el terror a la sensación de ser amados. Los manuales que llevaban consigo los misioneros estaban repletos de indicaciones sobre el diseño del escenario y qué imágenes debían aparecer en cada momento de la predicación. En el púlpito se recomendaba que estuvieran colocados Jesús y la Dolorosa, figuras que se utilizaban en los diferentes sermones, y que las imágenes de la parroquia sólo se colocaran el último día ${ }^{41}$. En el tablado de la predicación también se podían encontrar sogas, cadenas, espinas y otros elementos, como hachas encendidas. Otros misioneros señalaban la importancia que debían tener objetos piadosos, como medallas, crucifijos, rosarios o escapularios. Los misioneros buscaban atraer a cuanta más gente posible para acercarlos a la penitencia. Los iconos sagrados jugaban un papel esencial en este sentido. Por ello, los dos momentos más importantes se referían a dos sacramentos: la

\footnotetext{
titució Alfons el Magnàmin, Valencia, 2006 y Louis Châtellier, La religión de los pobres, Desclée de Brouwer, Bilbao, 2002 [1993].

39 Desde esta perspectiva, y como veremos más adelante, se puede explicar lo sucedido en la localidad cántabra de Limpias a finales de la segunda década del siglo XX.

40 Cartas Edificantes de la Asistencia en España, n. 2, 1904, p. 620.

${ }^{41}$ Ignacio Santos, Directorio para dar misiones, Imprenta del Corazón de Jesús, Bilbao, 1903, p. 23.
} 
confesión y la comunión general. El éxito de las misiones se medía por el número de comulgantes, especialmente si eran hombres. La intención era despertar en el creyente su autoidentificación como católico y que pudiera responder así en su día a día. De hecho, no se puede entender la intensa movilización católica durante las primeras décadas del siglo sin tener en cuenta todos estos aspectos.

A pesar de su carácter religioso, los vendedores ambulantes montaban sus tenderetes para vender alimentos y cualquier objeto piadoso. Las misiones populares atraían a multitud de personas de la localidad y de los pueblos aledaños. Y es que la Iglesia también se aprovechó de la técnica y de los avances industriales para potenciar su particular propuesta. De esta manera, se comenzaron a producir a gran escala y a precios asequibles un conjunto de objetos religiosos que fomentaron la piedad familiar y personal. Un niño que pertenecía a la congregación infantil de carácter jesuita describía en una revista de la organización cómo su madre le enseñó a rezar delante de la estatua mariana que tenían en casa. No podemos olvidar, como remarcó Thomas Kselman, que las principales figuras devocionales del catolicismo, como Jesucristo, María o el propio san José, participaban dentro de la metáfora familiar y la sustentaba ${ }^{42}$. Por esta razón, la guipuzcoana Florencia Sorazu y Aizpurúa, una reconocida mística concepcionista franciscana, recordaba en su autobiografía espiritual cómo:

«mis padres y abuelos eran muy católicos, siempre nos hablaban de Dios, de la Virgen y de los Santos, tanto que los primeros años de mi vida los pasé en un ambiente parecido al que rodeó la existencia de los primitivos cristianos. Como éstos, miraba a Jesús como Jefe de la familia, y a los Santos los identificaba con mis padres y abuelos, especialmente a San José, San Joaquín y Santa Ana, a los santos Apóstoles, y a San Ignacio de Loyola, Patrón de Guipúzcoa, singularmente venerados en mi familia $»^{43}$.

Asimismo, la industrialización de la imaginería religiosa también facilitó la gran expansión de las representaciones de la Inmaculada Concepción o todos los objetos relacionados con la consagración familiar al Sa-

42 Thomas A. Kselman, Miracles and Prophecies in Nineteenth- Century France, Rutgers University Press, New Brunswick, 1983, pág 96 y ss.

${ }^{43}$ María de los Ángeles Sorazu, Autobiografía espiritual, Universidad Pontificia de Salamanca/ Fundación Universitaria Española, Madrid, 1990, p. 93. 
grado Corazón de Jesús desde finales del siglo XIX. Y es que, como afirmó Jean Nagle, la devoción del Sagrado Corazón de Jesús, aunque interpretada desde parámetros antiliberales, fue un importante mecanismo para el avance en la creación de la individualidad moderna ${ }^{44}$. Salvando las distancias, como estableció agudamente Maitane Ostolaza para los colegios religiosos guipuzcoanos, esta espiritualidad católica participó de la creación del sujeto moderno en una combinación de modernidad y tradición ${ }^{45}$. El hecho devocional en la contemporaneidad conjugó lo colectivo con lo individual. Es más, su expansión favoreció la conformación de un sujeto religioso moderno dentro del catolicismo, que lentamente se afianzó como una forma de creencia individualizada, más personal, que se alejaba de la simple cultura religiosa, lo que había dominado hasta entonces, en una situación de pluralismo religioso o de conflicto sobre la secularización. El propio Kselman demostró que este individualismo religioso moderno no sólo podía ser achacado a las devociones eclesiásticas más ortodoxas, sino también a tradiciones religiosas populares ${ }^{46}$.

El proceso industrializador y sus transformaciones tecnológicas tuvieron sus efectos en la producción de retablos e imágenes para las nuevas iglesias, capillas y conventos que se abrieron durante la Restauración. En la mayoría de los casos, la producción fue seriada y sencilla, lo que le dio a las imágenes cierto carácter que las asemejaba entre ellas, por lo que perdían la fuerza artística y religiosa que habían alcanzado en los siglos anteriores. Por ello, Emile Verhaeren y Darío de Regoyos aseguraban que algunas de las imágenes antiguas que se encontraron por su viaje eran penetrantes, aunque lamentaban que el país cada vez se encontrara invadido por «las esculturas a la francesa, insípidas imágenes de confitería» ${ }^{47}$. No fueron los únicos en criticar esta moda, ya que con frecuencia se denunció lo que sucedía con las «nuevas iglesias de gusto exótico llenas de colorines y de purpurinas, con santos que parecen obras de confitería, no son tan sugestivas ni tiene ese aire de austeridad de las antiguas» ${ }^{48}$. Tam-

44 Jean Nagle, La civilisation du coeur. Histoire du sentiment politique en France du Xlle au XIXe siècle, Paris, Fayard, 1998, p. 138.

${ }^{45}$ Maitane Ostolaza, Entre religión y modernidad. Los colegios de las congregaciones religiosas en la construcción de la sociedad guipuzcoana contemporánea, Universidad del País Vasco, Bilbao, 2000, pp. 325-326.

46 Thomas A. Kselman, Miracles and Prophecies..., op. cit.

47 Emile Verhaeren y Darío de Regoyos, España negra, El Tilo, Bilbao, 2004, p. 18.

48 Rafael Larumbe, «Las campanas viejas de mi pueblo», La Baskonia, 30-XII-1922, p. 133 . 
poco se escapaban de la crítica los pasos de Semana Santa en algunas ciudades españolas. Quizá unos de los más discutidos fueron los de Bilbao, de los que se decía que dejaban «mucho que desear desde el punto de vista de la belleza artística» ${ }^{49}$. Tiempo después Rafael Sánchez Mazas reconocía también que

«los pasos eran toscos o medianos, las cohortes romanas tan exiguas que no llegaban a los doce soldados, nada de encapuchados penitentes o disciplinantes, alguna modesta cofradía, una bella urna de cristal para Cristo muerto y una delicada, pura, inolvidable Dolorosa, como un dolorido cristal, con dos lágrimas de diamante y un manto negro, de reina viuda castellana, loca de pena, como el de doña Juana la Loca. Pero corría por las calles un río de llamas de cera encendida y de conmovida piedad en los corazones» ${ }^{50}$.

Sin embargo, para muchos de los creyentes el problema no residía solamente en la belleza estética de las imágenes. En las leyendas populares, constantemente se hablaba de que habían sido precisamente las imágenes de los santos o de la Virgen las que habían determinado el lugar para la construcción de una ermita o de la iglesia parroquial. En otras ocasiones, las imágenes habían sido descubiertas milagrosamente sobre este lugar. Por lo que las imágenes antiguas guardaban un poder y una sacralidad que no podrían alcanzar jamás las modernas. En pleno período republicano el mensaje transmitido por una supuesta aparición mariana a un joven pastor vallisoletano era elocuente en este sentido, solamente aconsejaba que se debía sustituir la moderna efigie mariana de su pueblo por la antigua ${ }^{51}$. Lo que podría ser una anécdota intrascendente alcanza todo su sentido sentido desde esta perspectiva cultural. La sacralidad de las imágenes estaba, además, relacionada con la memoria comunitaria. Por ello, no es extraño que se mantuvieran creencias como las recogidas por José Miguel de Barandiarán en su trabajo de campo en el País Vasco rural:

«todavía subsiste en las sencillas mentes de algunos campesinos que ciertas imágenes de la Virgen que se veneran en las iglesias y ermitas, no son tales imágenes, sino verdaderas señoras de carne y hueso, mi-

\footnotetext{
49 El Nervión, 12-IV-1903.

50 Rafael Sánchez Mazas, Vaga memoria de cien años y otros papeles, El Tilo, Bilbao, 1993, p. 145.

${ }^{51}$ La Vanguardia, 26-III-1932.
} 
lagrosamente aparecidas y conservadas durante siglos. Y aunque esta creencia aparece hoy tan sólo como afirmación tímida, o se formula anteponiéndole el consabido decían nuestros abuelos, el hecho de haberla hallado en muchos pueblos del país vasco nos prueba que ha estado muy extendido aquí este género de animismo que, en definitiva, no es más que la idealidad pagana aplicada a las imágenes cristianas» ${ }^{52}$.

Sin embargo, el hecho va más allá de la creencia simple y supersticiosa de gentes analfabetas o de restos de cultos paganos anteriores. En realidad, estas certidumbres deben relacionarse con la idea de una comunicación comunitaria y directa con la divinidad. Con la convicción de que en las imágenes se encontraba algo más que una simple representación: era la mediación perfecta hacia la trascendencia. De hecho, la fe de la líder comunista Dolores Ibárruri se quebró cuando descubrió que la imagen mariana de su parroquia era «un espantapájaros», más si tenemos en cuenta que

«en aquella imagen pueblerina [de la Dolorosa] yo adoraba la representación de la virgen madre, cuyo corazón traspasado por siete puñales refulgía sobre el negro corpiño de terciopelo. Y, a veces, cuando el reflejo de los cirios se irisaba en las lágrimas de cristal incrustadas en el rostro de la virgen, parecía que ésta lloraba de verdad» ${ }^{53}$.

\section{El caso de Limpias: las imágenes traen un mensaje}

Sólo a partir de este ambiente sociocultural se puede llegar a explicar los fenómenos de los Cristos que comenzaron a mover sus ojos y bocas o a desprender sudores en diversos localidades españolas durante los años finales de la Restauración. Por ejemplo, en mayo de 1904, se anunciaba que los ojos de la Virgen de los Dolores de la iglesia de Santa María de Durango se habían movido ${ }^{54}$. Y así sucedió con mayor repercusión mediática en la localidad cántabra de Limpias, pero también posteriormente en los pueblos navarros de Piedramillera y Mañeru, en Gandía o en la locali-

52 José Miguel de Barandiarán, «Las Iglesias (continuación)», Eusko- Folklore. Materiales y Cuestionarios, LXXII, XII-1926, p. 48.

53 Dolores Ibárruri, El único camino, Castalia, Madrid, 1992 [1962], p. 121.

${ }^{54}$ El Liberal, 22-V-1904. 
dad granadina de Motril ${ }^{55}$. Algunos no escaparon de una lectura política, ya que irónicamente señalaban que estos prodigios se producían en lugares donde dominaban los mauristas ${ }^{56}$. Estos signos milagrosos se convirtieron en frecuentes durante la edad Moderna, momento en el cual se produjeron sudoraciones, llantos o sangrados de imágenes ${ }^{57}$. Sin embargo, el discurso antisupersticioso de la jerarquía española hizo que este tipo de manifestaciones fueran desapareciendo de la religiosidad local española con el paso del tiempo. A finales del siglo XIX, regresarían paulatinamente a la cultura devocional española con cierta fuerza, reflejando el ambiente europeo.

En la última semana de marzo de 1919, unos niños declararon haber visto mover los ojos de la figura del Cristo de la Agonía de Limpias durante una misión capuchina. Más tarde, y a lo largo de varios meses, el prodigio fue observado por cientos de visitantes. Un poema al Cristo señalaba la penitencia y la reforma en las malas costumbres que se estaban expandiendo ante la multitud de problemas: «grandes son, Jesús mío, mis agravios, / justos son, Jesús mío, tus enojos/ y aún quedan de mi culpa los resabios» ${ }^{58}$. Como hemos señalado anteriormente, en la misión se repetían situaciones cargadas de una gran intensidad emocional y las conversiones fueron importantes en número. Por eso mismo, no es difícil descubrir que durante los sucesos de aquellos días «todos temblaban, lloraban, gritaban, se agitaban, a impulsos de algo extraordinario que no sabían explicarse» ${ }^{59}$.

Rápidamente su fama se extendió llegando a recibir multitud de peregrinaciones, incluso alguna extranjera, siguiendo el modelo organizativo desarrollado en las peregrinaciones a Lourdes ${ }^{60}$. Fue la primera experiencia hispana con un modelo aparicionista moderno. Los defensores de esta señal llegaron a equiparar estos sucesos con las apariciones francesas, como «uno de los más grandes llamamientos de Dios a los hom-

55 William A. Christian, Moving Crucifixes in Modern Spain, Princenton University Press, Princenton, New Jersey, 1992.

56 Nuevo Mundo, 6-V-1921.

57 William A. Christian, Apariciones en Castilla y Cataluña: siglos XIV-XVI, Nerea, Madrid, 1990 [1981], p. 20.

58 Tomás Echevarría, Los prodigios de Limpias: ensayo histórico, artístico y teológico de su santísimo Cristo de la Agonía, Editorial del Corazón de María, Madrid, 1919, s. p.

59 Íb., p. 138.

${ }^{60}$ En Mundo Gráfico, 21-VII-1920, se señala la llegada de una peregrinación de fieles americanos. 
bres distraídos y descaminados» ${ }^{61}$. En la época era evidente que la localidad cántabra había sido un punto de encuentro de los católicos del norte peninsular. El impacto en el catolicismo español fue intenso. Y es que los prodigios se concentraron en varios meses a unos 100.000 visitantes, lo que inauguraba una nueva época de turismo religioso en España: eran algo más que turistas, pero también algo más que peregrinos al modo tradiciona ${ }^{62}$. Numerosas expediciones viajaron a Limpias a observar al milagro, y al ir a buscarlo lo encontraron. Incluso algunos obispos fueron protagonistas de las visiones prodigiosas, lo que ofrecía al fenómeno cierta oficialidad. Desde el propio catolicismo fue criticado por la subjetividad del hecho, del que daban cuenta más las personas que las pruebas empíricas. Sin embargo, los devotos se comenzaron a hacer con el rostro de Cristo de Limpias para sus hogares.

Con todo, quizá uno de los aspectos menos conocidos, pero más interesantes a nivel analítico fue el uso político del fenómeno hecho por la familia real húngara en su estancia en España, en la villa vizcaína costera de Lequeitio. El Cristo de Limpias se convirtió entonces en una metáfora nacionalista, al asimilarlo con la Pasión y la Crucifixión, y contra la revolución bolchevique antes incluso de la utilización de las apariciones lusas de Fátima ${ }^{63}$. No puede resultar extraño, ya que la pasión y el dolor estaba en el centro de la propaganda católica. Para muchos devotos católicos, no había lugar a dudas del mensaje que se pretendía lanzar, según la interpretación de los supuestos deseos del Cristo de Limpias realizada por un religioso capuchino:

«quiere que el Crucifijo no se destierre de ningún lugar, aunque sea para colocar allí otra cualquier imagen suya. Quiere ser proclamado Rey de la familia y de la sociedad; pero quiere que se le proclame y represente, no rodeado de majestad, pompa y comodidades terrenas, que nunca disfrutó en esta vida, sino con la insignia del dolor, que es la Cruz» ${ }^{64}$.

61 Pedro Santiago Camporredondo, El Santo Cristo de Limpias, Santander, Vicente Oria, 1920, p. 49.

62 Pedro Santiago Camporredondo, El Santo Cristo de..., op. cit., cifra en 200.000 en el primer año con un promedio de unas 550 personas cada día (p. 12). Por su parte, Jenaro Geijo, Limpias. El Cristo Milagroso, Santa Casa de Misericordia, Bilbao, 1967, rebaja la cifra a 120.000 (p. 19).

63 William A. Christian y Zoltán Krasznai, «The Christ of Limpias and the Passion of Hungary», History and Anthropology, 20/ 3 (2009), pp. 219-242.

64 Andrés de Palazuelo, El Santísimo Cristo de la Agonía de Limpias, Madrid, El Mensajero Seráfico, 1920, pp. 289-290. 
De hecho, el sufrimiento estuvo muy presente en el catolicismo europeo del siglo XIX, ya que se produjo una insistencia constante en el cuerpo doloroso de Cristo ${ }^{65}$. Por ejemplo, la Virgen se apareció en La Sallette con los instrumentos de la Pasión. Asimismo, se reactivaron y construyeron por toda Europa Via Crucis, una devoción que intentaba evocar la memoria del los sufrimientos de Jesucristo durante su pasión hasta el Calvario en Semana Santa. Como ya hemos señalado, la pasión se convirtió en un símbolo de las dificultades de la Iglesia frente a sus enemigos anticlericales ${ }^{66}$. Además, entre algunos devotos existía la firme convicción de la autenticidad de la reliquia guardada en la catedral de Turín, conocida popularmente como la Sabana Santa ${ }^{67}$. El sudario, sacralizado como la auténtica verónica que cubrió a Jesús en los momentos de la pasión, fue mostrada como una prueba más de su dolor y sufrimiento. Tampoco fue extraño el uso de instrumentos para la mortificación, como el cilicio cuya utilización se encontraba en las reglas de cartujos y carmelitas, con la pretensión de acompañar y unirse al sufrimiento de quien consideran el Redentor ${ }^{68}$.

Estrechamente relacionado con todo ello, estaba el antiguo fenómeno de los estigmatizados, es decir, personas que supuestamente recibían en su cuerpo los signos de la Pasión de Cristo, sobre todo en la Semana Santa, además de recibir otra serie de dones sobrenaturales, como la xenoglosia o la bilocación. Los estigmas se revitalizaron en la vida católica gracias a los dos casos más célebres en el siglo xx, la alemana Theresa Neumann y el capuchino Pío de Pietralchina, que se interpretaron como un mensaje de penitencia y misericordia ${ }^{69}$. Su repercusión en España no fue pequeña, por ejemplo, Neuman fue visitada por el sacerdote vasco Resurrección María de Azkue, quien escribió un artículo en la revista Reseña Eclesiástica en el que aseguraba que terminada su estancia en la localidad de Konnersreuth, sólo podía dar

65 Alain Corbin: «El dominio de la religión», en Corbin, Alain (ed.): Historia del cuerpo. (II) De la Revolución Francesa a la Gran Guerra, Taurus, Madrid, 2005, p. 59.

${ }^{66}$ Así Jean Béraud en su cuadro Via Crucis (1894) representó el enfrentamiento entre los clericales y anticlericales. En esta pintura podemos ver a una monja rodeada de niños que arrodillados rezan al paso de Cristo con la cruz, mientras una pareja de la alta sociedad se ríe de él y un maestro laicista azuza a sus alumnos para que le apedreen.

67 «El Santo Sudario de Turín», La Hormiga de Oro, 4-IV-1903.

68 Alain Corbin, «El dominio de...», op. cit., p. 76.

69 Sergio Luzzato, Padre Pio. Miracoli e politica nell'Italia del Novecento, Einaudi, Torino, 2007. 
«gracias a Dios por haberme proporcionado ocasión de admirar y contemplar allí, con más evidencia que nunca, la grandeza de su misericordia con nosotros. Viva largos años como hoy la angelical esposa del Salvador Teresa Neumann, para gloria de Dios, sostén de los sacerdote en su augusta misión y conversión de herejes e incrédulos y enfervorización de católicos tibios» ${ }^{70}$.

A partir de los sucesos de Limpias, los anticlericales no perdieron el tiempo en utilizar estas manifestaciones para elaborar sus críticas. El fenómeno llegó a ser utilizado por la ácida pluma del columnista de $E l \mathrm{Li}$ beral bilbaíno Teodosio Mendive, para hacer una crítica de la situación política del país. En Melilla, otro Cristo lloraba en una iglesia regentada por capuchinos y lo aprovechaba para asegurar que era

«un milagro simbólico, un milagro muy bonito en el que forzosamente hay que creer. Yo creo en él y creo en esas lágrimas y en esa imagen que, ante la guerra de Marruecos, no ha podido conservar su impasibilidad estatuaria, no ha podido contenerse sereno e indiferente, no ha podido menos de manifestar su opinión sobre el problema de Marruecos» ${ }^{71}$.

Al final, el Cristo Limpias se quedó a medio camino. No consiguió la aprobación de la Iglesia, aunque no chocaba esencialmente con el mensaje que se venía transmitiendo desde las apariciones francesas decimonónicas. Sin embargo, la emotividad y la dificultad para dar credibilidad a un fenómeno tan subjetivo torpedeó los intentos de oficializarlo. Aún siguió despertando cierta devoción entre los creyentes, aunque las oposiciones eclesiásticas le hirieron de muerte. En todo caso, lo expresado en este apartado debe tenerse en cuenta al acercarse al catolicismo español de entresiglos, en el corazón se encontraba la posibilidad de la intercesión divina en defensa de la Iglesia.

\section{La intercesión divina}

Como ha demostrado Jean Delumeau, el catolicismo reactivó tras la Reforma una serie de elementos - como las procesiones, escapularios o

70 Resurrección María de Azkue, La estigmatizada de Konnersreuth, Imprenta de E. Subirana, Barcelona, 1929, p. 19.

71 El Liberal, 27-V-1922. 
el rosario - para fortalecer la sensación de seguridad y paliar de esa manera las angustias de unas personas que demandaban la protección divina ante catástrofes naturales, como tempestades o epidemias, y la preocupación por su salvación eterna ${ }^{72}$. Se pretendía alcanzar cierto sentimiento de certeza ante la adversidad probable, tanto a nivel comunitario como personal. La idea de la presencia sobrenatural cotidiana facilitaba la creencia en la posibilidad de la intercesión ante el mal. Cada pueblo tenía su propio santo protector de la cosecha y de la vida comunitaria. Resultaba habitual que los sacerdotes rurales bendijeran los campos para que no se malograra la cosecha. Pero estas realizaciones no se encontraban sólo en el mundo rural, también se buscaba el favor en otro tipo de inauguraciones urbanas, ya fuera en un campo de fútbol o en la puesta en marcha de un hospital. Los objetos bendecidos estaban protegidos y buscaban el favor divino. En el ámbito rural era bastante común tener en casa una vela bendecida para encenderla cuando alguien caía enfermo ${ }^{73}$.

En cierta medida, se necesitaba mantener el control ante coyunturas en las que los hombres lo perdían por completo. En situaciones extremas se hacían rogativas públicas, a las que se sumaba una procesión para el cese de la epidemia. Cuando la epidemia acababa lo normal era desarrollar un Te Deum como acción de gracias a Dios. Pero también en el ámbito privado se usaban remedios religiosos contra los problemas. Por poner un ejemplo, durante la dura epidemia de cólera de 1885 se buscaron remedios religiosos anticoléricos, entre los que se hizo bastante reconocido el agua bendita de san Ignacio de Loyola, que también era efectiva en partos complicados y protegía contra todo tipo de pestes ${ }^{74}$. Tampoco era extraño erigir una estatua en honor del santo o virgen que había sido proclive a la localidad. Por otro lado, se hacían peticiones y se celebraban procesiones como rogativas para la lluvia cuando la meteorología no acompañaba los intereses de los labradores. O conjuros contra el mal tiempo para la cosecha e, incluso, en muchos pueblos se creía que el párroco tenía un libro secreto

72 Jean Delumeau, Rassurer et protéger. Le sentiment de sécurité dans l'Occident d'autrefois, Fayard, Paris, 1989.

${ }^{73}$ Resurrección María de Azkue, Euskalerriaren Yakintza, vol. 1, Espasa Calpe/ Euskaltzaindia, Madrid, 1959, p. 179.

74 El mayor difusor fue el padre Luis I. Fiter, El Agua de San Ignacio, Librería y Tipografía Católica, Barcelona 1897 o ÍD., Celestial protección de S. Ignacio de Loyola dispensada á las madres de familia, Imprenta de Henrich y Ca en Comandita, Barcelona, 1894. Por ejemplo, en este último texto habla de los poderes de San Ignacio para resucitar a los niños que nacieron muertos o murieron al poco de nacer (p. 5). 
para ello ${ }^{75}$. Estaba claro, el tiempo podía expresar la opinión de la divinidad. Sin ir más lejos, en las celebraciones de la proclamación del dogma de la Inmaculada Concepción a mediados del XIX se interpretó como un gesto de la divinidad el cambio metereológico acaecido ese mismo día en el momento que el Pío IX invocaba al Espíritu Santo y a toda la Corte Celestial ${ }^{76}$. En las localidades marineras también se producían procesiones y oraciones para el buen estado de la mar y la protección de los pescadores. Se usaban cruces o ramos bendecidos contra los rayos.

Pero esta creencia en la posibilidad de la intercesión divina tenía otra cara menos amable: la idea de un Dios todopoderoso que regía los destinos de los seres humanos y que podía castigar a los pecadores ${ }^{77}$. En una conferencia el político nacionalista vasco Federico Zabala y Allende aseguró que «todos los estados [estaban] bajo el Imperio de Dios y no es extraño que si se desvían los castiguen ${ }^{78}$. Por su parte, durante la epidemia de cólera de 1885 algunas ciudades españoles fueron recorridas por procesiones infantiles que buscaban la misericordia divina. Estos niños entonaban una coplilla que decía lo siguiente: «iAplaca, Señor tu ira,/ tu justicia y tu rigor,/ dulce Jesús de mi vida;/ misericordia, Señor!»79. También habrá que señalar que la devoción y la piedad crecían en las dificultades, hasta el punto de considerar a el fracaso colonial español de fin de siglo como un «castigo del cielo» por la deriva del país ${ }^{80}$. Por las mismas fechas, un opúsculo del Apostolado de la Oración aseguraba que las colonias se habían convertido «en minas de avaros y refugio de tunos» por lo que Dios castigaba al país ${ }^{81}$.

75 José Ignacio Tellechea Idígoras, Tapices de la memoria. Historia clínica 279.952, Sígueme, Salamanca, 2003, p. 68.

${ }^{76}$ Cit. en Antonia Amor Robles, «Escenografía teatral, festividad y decoración: el dogma de la Inmaculada y su proclamación en la Roma de Pío IX», Boletín de Arte, 22 (2001), pp. 239.

77 Y que servía para satirizar desde el librepensamiento como cuando un articulista aseguraba ante varias catástrofes: «quedo convencido una vez más de lo caritativo, de lo misericordioso y de lo justo que es el Dios de la Biblia y el Dios del Vaticano» (Las Dominicales, 4-V-1906).

78 «La Providencia y los castigos de las naciones», en Archivo del Nacionalismo Vasco/ Fondo Zabala: 17-2.

79 Cit. en Juan José Fernández Sanz, «Actitud y comportamiento de la Iglesia ante el cólera de 1885», Hispania Sacra, 85 (1990), p. 79.

80 El Basco, 19-I-1898.

81 Los religiosos españoles en Filipinas, Administración del Apostolado de la Prensa, Madrid, 1898, p. 57. 
A un nivel más personal, una larga serie de santos, escapularios o de vírgenes locales servían como mediadores ante la enfermedad, que en muchos casos lindaban con la ortodoxia eclesiástica, sin que por ello dejaran de ser potenciados por los sacerdotes locales. La Virgen y el Sagrado Corazón se conjugaban en la mediación con el santo particular de la familia, ofreciendo así la seguridad que causaba la piedad doméstica. Tampoco era extraño encontrarse en diversas publicaciones religiosas con una lista de $«$ santos protectores contra enfermedades y males ${ }^{82}$. Un ejemplo paradigmático se encuentra en el recuento de las gracias conseguidas por parte de san Antonio que llenaban las paginas de El Pan de los Pobres. Popularmente, estos santos tenían mucho éxito y sus hagiografías los presentaban, al igual que a los mártires, como seres sobrenaturales que nunca habían pertenecido al mundo. Y es que aún se seguía acudiendo a los templos que guardaban reliquias en busca de milagros y ayudas divinas. $\mathrm{Mu}-$ chas de estos lugares tenían una larga tradición curativa y devocional. Existían remedios para todos los problemas. Asimismo, algunos santuarios estaban especializados en eliminar el mal de ojo o evitar la posesión demoníaca. El peligro de estas devociones se señalaba constantemente, ya que confundía con frecuencia para muchos sacerdotes «la religión con la superstición ${ }^{83}$. Sin embargo, los propios religiosos solían publicitar las facultades de su elemento mediador.

Por otro lado, si bien es cierto que durante el ochocientos no se produjo la intensa expansión vivida en los siglos medievales en relación al comercio de reliquias, ya fueran reales o falsas, estas seguían siendo un importante aspecto de la devoción de la gente y el motor de numerosas peregrinaciones. Fundamentalmente reavivaban la devoción y la afianzaban, ya que se convertían para sus defensores en «un poema de fuerte enseñanza religiosa y moral para las multitudes» ${ }^{84}$. No cabe desmerecer el pretendido poder que aún seguían gozando las reliquias en el catolicismo de entresiglos. Unamuno recordaba que en san Isidoro de León «su abad solemne, don Jenaro Campillo, me sacó los demonios del cuerpo con la mandíbula de san Juan Bautista, que allí se venera. Es una historia que he

${ }^{82}$ Ecos Religiosos, 30-VIII-1900, p. 367. En la lista aparecían los santos que protegían contra la fiebre, la epilepsia, la parálisis, las pestes, los dolores de cabeza, contra la sequía e, incluso, los males de ojos.

${ }^{83}$ R. V. Ugarte, «Hijo mío, si estás enfermo no te descuides», El Mensajero del Corazón de Jesús y del Apostolado de la Oración, t. LX, IX-1915, p. 261.

${ }^{84}$ Isidro Gomá, El valor educativo..., op. cit., pp. 251-252. 
de contar algún día para edificación de las almas sencillas que crean en la mandíbula del Bautista y en mis demonios, y no sé si para regocijo de los espíritus volterianos» ${ }^{85}$.

Las reliquias de mártires recibieron un nuevo impulso durante los siglos XVIII y XIX, tanto es así que el propio papa Pío IX prohibió que se sacaran cuerpos momificados y reliquias de Roma, donde se habían descubierto más cuerpos en las catacumbas ${ }^{86}$. Éstos también se trasladaron a España hasta su prohibición, aunque en 1928 todavía llegaban los restos de santa Columba a San Sebastián ${ }^{87}$. Hay que tener en cuenta que los milagros eran comprendidos como signos divinos que testificaban y aprobaban el mensaje que se estaba intentando transmitir. La mayoría de los católicos entendía que las manifestaciones milagrosas otorgaban protección de lo divino y ofrecían avisos para el avivamiento de las devociones.

«no hay más que dos caminos: creemos o no creemos; si [creemos] verdaderamente en la existencia de un Dios afirmamos nuestro pensamiento, ¿acaso no es ya necio, sino hasta pueril pensar, que quien un mundo creó, o da lo mismo que quita la vida, no pueda hacer mover los ojos a esta imagen suya? No, no hay más que dos caminos: o se cree o no se cree. Si hay fe no hay razón científica; si hay razón científica, no hay $f e{ }^{88}$.

El milagro era, por tanto, entendido como un sello de divinidad: las curaciones sobre las leyes naturales probaban la omnipotencia de Dios. Además, se consideraba que los milagros eran buenos «porque se robustece con ellos la fe de los buenos creyentes, se alienta su esperanza en el triunfo definitivo de la verdad, se vigoriza y enardece más su espíritu para seguir luchando sin tregua ni descanso en pro de la verdad combatida» ${ }^{89}$.

85 Miguel de Unamuno: Obras completas, I. Paisajes y ensayos, Escélicer, Madrid, 1966, pp. 392-393.

86 Philippe Boutry, «Les saints des Catacombes. Itinéraires français d'une piété ultramontaine (1800-1881)», Mélanges de l'Ecole française de Rome. Moyen- Age. Temps Modernes, 91/ 2 (1979), pp. 875-930.

${ }^{87}$ Francisco Etxebarria et al.: «El interés popular por las momias. De la curiosidad natural a la religiosidad popular», Zainak, 18 (1999), pp. 309-319.

${ }^{88}$ Hesperia, «Notas de mi cuaderno», Alrededor del Mundo, 15-IX-1928.

89 José M. Galdácano, Catequesis sensibilizada: colección de pensamientos, imágenes, comparaciones, y rasgos históricos para uso de los dedicados a la enseñanza de la doctrina cristiana, Imprenta y Librería de José de Astuy, Bilbao, 1912, p. 40. 
En la Europa de entresiglos lo milagroso se contrapuso a la ciencia, y el epítome de este enfrentamiento fue el santuario mariano de Lourdes. El centro milagroso de la catolicidad se encontraba en dicha localidad francesa, aunque posteriormente el testigo lo recogería Fátima por su marcado carácter anticomunista ${ }^{90}$. El mundo católico vivió desde el pontificado de Pío IX una efervescencia devocional ligada a sucesos milagrosos. Para algunos estudiosos en la época se vive una cierta sed de milagros. De esta manera, la devoción mariana ofrecía según los católicos multitud de gracias temporales, ya que como creía Remigio Vilariño, «sólo Lourdes ha sanado más enfermos que todos los médicos juntos. [Y] la Virgen de Begoña habrá salvado más náufragos que todas las sociedades de salvamento unidas ${ }^{91}$. Así la edad de oro mariana trajo consigo la revitalización de las mariofanías o apariciones de la Virgen. En muchos casos estas devociones eran espontáneas y peligrosas para la jerarquía, aunque no saliesen del marco simbólico establecido durante siglos por la Iglesia católica. No olvidemos que también estaban muy presentes en la religiosidad española de la época la memoria de los milagros relacionados con la eucaristía, como destacaba la multitud de estudios presentados en diversos congresos eucarísticos ${ }^{92}$.

La fama de Lourdes traspasó fronteras y, durante el XIX, facilitó la internacionalización de la cultura visionaria. En el santuario se dieron cita millones de peregrinos; una multitud representada como pacífica que poco tenía que ver con las multitudes proletarias y urbanas que amenazaban el orden burgués ${ }^{93}$. Fueron numerosas las peregrinaciones de católicos a Lourdes, considerada como la auténtica fortaleza donde se había

90 Como ha destacado Paolo Apolito, Internet y la Virgen. Sobre el visionarismo religioso en la red, Laertes, Barcelona, 2007 [2002], p. 58: «la aparición se identificaba tanto con un lugar como con una persona».

${ }^{91}$ Remigio Vilariño, Devoción a la Virgen, El Mensajero del Corazón de Jesús, Bilbao, 1919 , p. 23.

${ }_{92}$ Eustaquio Ugarte de Ercilla, España eucarística (tradiciones eucarísticas españolas), Imp. del Asilo de Huérfanos, Madrid, 1911.

93 Gabriel Tarde escribió entonces en La opinión y las masas: «no podemos confundir las multitudes suplicantes y procesionales que los miembros del clero dirigen en Lourdes con las multitudes revolucionarias y ruidosas suscitadas por un jacobino, o las multitudes miserables y hambrientas de huelguistas dirigidas por un sindicato», cit. en Eduardo Cintra Torres, «A multidão religiosa de Lourdes em Zola e Huymans», Análise Social, 184 (2007), pp. 733-755 (la traducción se ha hecho de la cita en portugués). 
iniciado la reconquista rural de Francia ${ }^{94}$. Como han puesto de manifiesto diversos estudios, Lourdes no puede ser entendido sin el ferrocarril, como después no se puede comprender la expansión popular de Fátima sin la radio y el avance de la alfabetización ${ }^{95}$. No podemos deslindar la expansión de la iconografía mariana, que adquiría claros perfiles de Lourdes, de esta sed de milagros que recorría el continente, como demuestra la multiplicación de imitaciones de la gruta de Lourdes a lo largo de toda la Europa católica. De hecho, la aparición de la virgen en la Bélgica de entreguerras en la localidad de Beauraing se produjo en una réplica de la gruta de Lourdes. Otro de los ejemplos significativos de la época fue la medalla milagrosa de Catherine Labouré, que contenía un mensaje inmaculista que certificó Pío IX y que alimentó la política de modernidad defensiva católica ${ }^{96}$. Es decir, se trataba de algo más que simple imaginería devocional.

Y dentro de este juego de devociones milagrosas y signos divinos se asentó una cultura profética a la que se enfrentó con dureza la Iglesia a través de las disposiciones del Santo Oficio ${ }^{97}$. En cualquier caso, no era extraño escuchar llamadas a visitar los centros de apariciones marianas, ya que ante un «mundo lleno de pecados» y el castigo de Dios por ello, la Virgen señalaba un remedio: la penitencia ${ }^{98}$. No es sorprendente debido a que el discurso que establecía el enfrentamiento entre el Bien y el Mal se situaba en el centro y encontraba su posición en las propias escrituras: la historia de la humanidad era recorrida por esta lucha, en aquellos años se jugaba un episodio más, quizá el definitivo. Y es que en muchos casos no había ninguna distinción alegórica, los sucesos venideros serían los de un apocalipsis inminente:

«en Lourdes constan predicciones graves para la humanidad pecadora. Y en La Salette se anuncian. Y en Fourvieres continúan. Y Francia se divorcia del Vaticano. ¿Será esa pobre nación donde comiencen suce-

94 Remigio Vilariño, «El triunfo de la causa católica en Francia», El Mensajero del Corazón de Jesús y del Apostolado de la Oración, t. LVII IV-1914, p. 302.

${ }_{95}$ Ruth Harris, Lourdes: body and spirit in the secular age, Penguin, London, 1999.

96 Sobre la Medalla Milagrosa, Richard D. E. Burton, Blood in the City. Violence and Revelation in Paris, 1789-1945, Cornell University Press, 2001, pp. 118-129.

${ }^{97}$ Hilaire Multon, «Catholicisme intransigeant et culture prophétique: 1 'apport des archives du Saint- Office et de l’Index», Revue historique, 621 (2002), pp. 109-137.

98 R. Rosé, «Peregrinación al Santuario de Nuestra Señora de Lourdes», Revista Popular, 29-VIII-1889, pp. 135-138. 
sos apocalípticos? Porque los días de la suprema lucha se hallan próximos y la Nave de Pedro se apresta a sufrir tempestad que en lo porvenir se cierne» ${ }^{99}$.

Pero no sólo se producían este tipo de interpretaciones a nivel popular. El propio Alfonso XIII fue un ejemplo de la amplitud de estas tesis en el campo católico ${ }^{100}$. De hecho, en un discurso ante Pío XI a finales de 1923 hizo una referencia explícita a las populares profecías de san Malaquías, que habían resultado ser una falsificación a posteriori de los hecho que supuestamente profetizaba ${ }^{101}$. El propio Benito Jerónimo Feijoo ya las había atacado, pero seguían en circulación engañando a los más crédulos y alimentando las teorías más variopintas ${ }^{102}$. No es extraño, de todas formas, que el propio monarca español en plena dictadura le insinuara al Papa que

«solemnemente os prometemos, Santo Padre, que si un día, en cumplimento de la divisa que, según San Malaquías corresponde a vuestro Pontificado - fides intrepida - , la fe exigiera de los católicos los mayores sacrificios, no regatearían los españoles ninguna clase de sacrificios, si en defensa de la fe perseguida, nuevo Urbano II, levantárais una Cruzada contra los enemigos de nuestra sacrosanta Religión, España y su Rey, fidelísimos a vuestros mandamientos, jamás desertarían del puesto de honor que sus gloriosas tradiciones les señalan por el triunfo y por la gloria de la Cruz, que junto con ser bandera de la fe, es también bandera de la Paz, de la Justicia, de la Civilización y del Progreso» ${ }^{103}$.

Aún gozaban de crédito, más si se tiene en cuenta que la crisis de fin de siglo en ocasiones se había vivido como la cercanía del fin del mundo ${ }^{104}$. Rafael Pijoán, quien fue capellán de honor de la monarquía, escribió un libro sobre las profecías en el que se concluía que «el final cataclismo» estaba cercano:

99 Petronilo Vicente Vélez, Realidades: estudio religioso, social y político, Imprenta Moderna, Barcelona, 1906, p. 15.

100 Julio de la Cueva, «El rey católico», en Javier Moreno Luzón (ed.); Alfonso XIII: un político en el trono, Marcial Pons, Madrid, 2003, pp. 280-306.

101 Mensajero del Corazón de Jesús y del Apostolado de la Oración, XI-1912.

102 Benito Jerónimo Feijoo, Teatro crítico universal, D. Joachin Ibarra, Impresor de Cámara de S. M., Madrid, 1773, pp. 110-118.

${ }^{103}$ El texto está trascrito en Fernando Soldevilla, El Año Político. 1923, Imprenta y Encuadernación de Julio Cosano, Madrid, 1924, p. 422.

104 Hans Hinterhäuser, Fin de siglo. Figuras y mitos, Taurus, Madrid, 1998 [1997]. 
«esta generación no pasará sin que se cumplan estas cosas; porque el fin del mundo llegará al terminar la lista de los Papas de la Profecía de San Malaquías. Por consiguiente, un poco más de tiempo, y el martillo del reloj eterno va a dar la última campanada para la descendencia de Adán» ${ }^{105}$.

Por lo tanto, seguía existiendo un poso que dejaba la puerta abierta a ese profetismo que en ocasiones tenía amplia recepción social. Aunque ya entonces fueran unas profecías desacreditadas que sólo reaparecían con ocasión de las diferentes elecciones papales en los medios de comunicación $^{106}$. Este profetismo apocalíptico no se escapa de la iconografía corazonista del Cerro de los Ángeles. No en vano, en 1925 dentro de una campaña por remozar el entorno de la construcción se afirmaba que Alfonso XIII había «asumido una alta representación histórica superior a la misma realeza. No es un Rey: es el Rey; no es siquiera una Monarquía: es la esencia inmortal de las monarquías cristianas, que prefiere la Cruz sin la Corona a la Corona sin la Cruz» ${ }^{107}$.

\section{A modo de conclusión: no sólo se vive de política...}

Hablando de la devoción de las aldeas españolas un columnista a principios de siglo escribía: «los cronistas de la actualidad nos pasamos la vida comentando los sucesos sensacionales, las costumbres, los estados del espíritu de los grandes centros de población; y entre tanto, se nos escapa todos los días el alma grande de las cosas infinitamente pequeñas» ${ }^{108}$. La intención de este trabajo ha sido elaborar una aproximación indiciaria al papel jugado por las imágenes religiosas dentro de la cultura católica de la Restauración. El historiador religioso debe acercarse a esas «cosas infinitamente pequeñas» de las que hablaba nuestro cronista. Parece evidente que los historiadores deberíamos aprender a

105 Rafael Pijoán, El siglo xx y el fin del mundo según la profecía de San Malaquías, Hormiga de Oro, Barcelona, 1941 [1914], p. 282.

${ }_{106}$ Un completa reseña crítica de las mismas, precisamente ante la avanzada edad de León XIII, en Eloy Bullón, «Las profecías de los Papas», La Ilustración Española y Americana, 30-X-1901, pp. 3-7.

107 Cit. en Luis Cano, Reinaré en España. La mentalidad católica a la llegada de la Segunda República, Encuentro, Madrid, 2010, p. 167.

108 Antonio Cortés, «Las devociones de la aldea», El Liberal, 5-VI-1904. 
observar lo inesperado y reconocer que nuestro trabajo se asemeja a una escapada pesquera. No hemos sido educados para ello, pero la experiencia del desempeño de nuestro oficio nos confirma lo cambiante que es el pasado. Es imposible acercarse a las imágenes sagradas sin ir más allá del propio objeto de estudio. Como se ha podido comprobar, la historia religiosa es una madeja interpretativa y elusiva en la que aparecen fenómenos interconectados por la vivencia espiritual relacionada con la imaginería sagrada.

En conclusión, las imágenes tuvieron repercusiones en la vida cotidiana de muchos católicos de entresiglos y en su interpretación de la realidad. Su interés, por tanto, transciende la unidireccional lectura de lo estético o de los análisis estilísticos. Detrás de las huellas dejadas por estas imágenes religiosas nos encontramos ante una forma de entender el mundo y de relacionarse con él. A través de este breve recorrido, hemos descubierto que existen algunas implicaciones sociales, antropológicas y políticas inexcusables. Siendo conscientes de ello, podremos desentrañar algunas claves espirituales para entender elementos centrales de la contemporaneidad española. Quizá haya llegado el momento de dejar en segundo plano las dimensiones políticas del fenómeno religioso, para embarcarnos en la aventura de entender cómo vivían su creencia los católicos del período restauracionista (y, por otra parte, también los anticlericales). La religión es un fenómeno tan elusivo al científico social que necesita de acercamientos interdisciplinares y caleidoscópicos ${ }^{109}$. Y es que no sólo de política vive el ser humano.

La religiosidad es mucho más que prácticas y creencias, ya que también incluye una fe, una identidad y está relacionada con mecanismos vitales no cognitivos, como las emociones ${ }^{110}$. No se pueden jerarquizar las identidades, entendiendo que somos seres polidentitarios, la construcción de la identidad individual y de las identidades sociales se desarrollaron dentro de un proceso mucho más concéntrico y menos estático de lo que creemos. La iconografía católica participaba cotidianamente de la vida de las personas y conformaba un depósito de memoria familiar y comunitario que se entrelazaba con lo local, lo regional y/o lo nacional. Cualquier

109 Sandrine Kott, «Éléments pour une histoire sociale et culturelle de la religion en Allemagne au xixe siècle», Bulletin de la Societé d'Histoire Moderne et Contemporaine, 48/ 4 bis, (2001), p. 92.

110 David Lyon, Jesús en Disneylandia. La religión en la posmodernidad, Cátedra, Madrid, 2002, p. 47. 
análisis de la relación entre nación y catolicismo en la España contemporánea debería iniciarse desde este ámbito. La autoidentificación de los católicos comenzaba en el hogar y tenía repercusiones en la esfera pública. No podemos desatender, por tanto, el fenómeno de la «politización devocional» que aconteció entonces en el continente europeo ${ }^{111}$. Se trataba de un esfuerzo eclesial por amoldarse a los tiempos y reconstruir su posición en la realidad política del momento. Las imágenes sagradas jugaban un papel esencial en este proceso. Por suerte, hemos descubierto la importancia del tema gracias al análisis de la violencia anticlerical ${ }^{112}$. Pero nos queda ir más allá para conocer la vivencia espiritual de los españoles de entresiglos.

111 Daniele Menozzi, «La Chiesa cattolica», en Giovanni Filoramo y Daniele Menozzi (eds.), Storia del cristianessimo. L'età contemporanea, Laterza, Roma, 2001, pp. 159-166.

112 Manuel Delgado, La ira sagrada: anticlericalismo, iconoclastia y antirritualismo en la España contemporánea, Humanidades, Barcelona, 1992; Juan Manuel Barrios, Iconoclastia (1930-1936). La ciudad de Dios frente a la modernidad, Universidad de Granada, Granada, 2007; o Bruce Lincoln, «Exhumaciones revolucionarias en España, Julio 1936», Historia social, 35 (1999), pp. 101-118. 